\title{
An expedition to Palawan, PhilipPines, AND ANOTHER NEW
}

\section{NEPENTHES SPECIES: NEPENTHES LEONARDOI}

\author{
Stewart M cPherson • 61 Lake Drive $・ H a m w o r t h y \cdot P o o l e \cdot D o r s e t ・ B H 15$ 4LR・UK • stewart@ \\ redfernnatural history.com
}

Keywords: Nepenthes leonardoi, Schom-carp Peak, Palawan, Philippines.

In N ovember 2010, I returned to the Philippines to undertake my fifth expedition to the island of Palawan in search of Nepenthes. M uch had changed since my first trip in 2007. A that time, just two palaweño Nepenthes were generally recognized - the lowland N. philippinensis and the highland N. mira. The mysterious Nepenthes deaniana had been discovered and named a century earlier, but it had never been rediscovered in the wild, and even the locality where it had originally been found was not known for it did not appear on any maps, neither modern nor old. Since all herbarium specimens of $\mathrm{N}$. deaniana had been lost when the M anila herbarium burned at the end of World War II, it remained uncertain whether $\mathrm{N}$. deaniana was in fact, distinct from N. mira or whether the two plants were the same.

During 2007, I spent three weeks in Palawan with Alastair Robinson and Volker Heinrich. After several unsuccessful efforts, we rediscovered $\mathrm{N}$. deaniana together, after deducing that the plant had originally been discovered on Thumbs Peak, a mountain near the capital of the island, Puerto Princesa (M cPherson 2009). We also climbed to the unexplored summit of M ount Victoria to discover a new giant Nepenthes species which we named N. attenboroughii, and we explored Palawan's highest peak to find a further unnamed N epenthes plant, which was later named N. mantalingajanensis by A ndreas Wistuba and J oachin Nerz who had encountered that plant several years earlier. M ore recent expeditions revealed two more new Nepenthes species; N. gantungensis on M ount Gantung, and N. palawanensis on Sultan's Peak.

The recent discovery of so many new Nepenthes on Palawan, and also on neighboring islands has demonstrated that the diversity of the genus across the Philippines is considerably greater than had previously been assumed. Ever since my first visit to Palawan four years ago, I always wondered why the island had not attracted interest earlier from botanists and, in particular, from Nepenthes enthusiasts. Palawan lies seductively close to the isle of B orneo - the great epicenter of the diversity of the genus. The short distance from B orneo, and the similar habitats which it offers, makes Palawan a logical candidate for N epenthes colonization and diversification. M ost of B orneo's N epenthes species are highland taxa, and similar to that island, Palawan abounds in peaks and uplands, and also offers considerable geological diversity - including many ultramafic mountains that on Borneo commonly harbor endemic Nepenthes.

Palawan's geography also makes it very interesting. It is a long, narrow island the lies obliquely north of Borneo - at only $40 \mathrm{~km}$ at its widest point, most of its mountains are quite accessible and relatively easy and fast to climb, indeed none are above $2085 \mathrm{~m}$. D espite the low height of Palawan's peaks, their exposure to the oceanic trade winds and seasonal rainfall cause their natural altitudinal vegetation zonation to be greatly compressed, to the extent that the summits of most of Palawan's mountains harbor a (strikingly narrow) strip of mossy highland plant life (including Nepenthes), which on Borneo and Sumatra would be expected to occur at much higher altitudes.

Yet throughout the $20^{\text {th }}$ century, Palawan's alluring highlands remained seldom visited and very little explored. The lack of visitors was in part due to violent Islamic separatist movements which had long festered in the south of the island. Although the violence recently cooled, and has now 
largely ended, and the island is starting to attract significant numbers of tourists, it is no exaggeration to state that still today the summits of many mountains on Palawan remain completely unvisited and unstudied in terms of the flora and fauna which they hold - particularly peaks and ridge tops that surround large massifs that have only recently been summited.

For all of these reasons, I have always found Palawan to be especially alluring. The friendly palaweño people, the wonderful cuisine and interesting indigenous cultures also added to its appeal. A nd so, last N ovember I set out once again, this time in the company of two friends and Nepenthes experts, Greg B ourke, and $M$ ark J aunzems, and a Filipino friend and climbing enthusiast J ehson Cervancia. Our goal was to return to the V ictoria M assif - a complex of mountains home to $\mathrm{N}$. attenboroughii and $\mathrm{N}$. palawanensis. In the north of the Victoria M assif, there lies a very interesting $\mathrm{U}$-shaped mountain system that is demarcated by high ridgetops that tightly enclose a river and drainage system on the northern, eastern, and southern sides. This U-shaped mountain complex does not appear to have been explored previously. I found no records of any earlier expedition prior to the trip, and still do know of any. Indeed, it does not even have a formal name - it does not appear on most maps and charts, and where it is depicted, it is usually known incorrectly under the name "B row Shoulder", a title that actually refers to a high and conspicuous separate peak further to the west.

On previous expeditions, I had noted this nameless $U$-shaped complex as an area to be of great interest for future exploration for N epenthes. From the lowlands, I had stared up at its summit across rice padis and water buffalo, and caught brief glimpses through openings in the clouds and mist in the early morning. I had thought that the summit areas appeared perfect for finding new Nepenthes - I had seen montane vegetation on the ridgetops that I could view, and these mountains lay disjunct from the rest of the Victoria M assif, and so logically could potentially harbor distinct Nepenthes populations that may be sufficiently isolated to have evolved as distinct species.

On arriving back in Palawan this time, and viewing the mountains once more, they looked more interesting than ever - particularly after a tricycle-driver whom I had hired promptly informed me than on "those mountains" (i.e. the M ountV ictoria massif), there is a "flower that eats mice". He had not seen the plant himself, but read about it in newspapers and on the television. No doubt, he was referring to $\mathrm{N}$. attenboroughii, which had received media attention worldwide a few years earlier after A lastair, Volker, and I published our description of it as being one of the largest pitcher plants.

So, on N ovember $16^{\text {th }}$, G reg, M ark, J ehson, and I set out to reach the northern ridgeside arm of this complex. We anticipated that trails would most likely penetrate the lowland rainforest close to the base of the mountain since hunters, animal-trappers, and resin collectors work widely throughout Palawan's lowland forests, and most probably would be active here. We expected that the trails would end after we had gained one thousand meters or so in elevation since at this altitude, the vegetation becomes thinner and more montane which causes both the game and the resin trees to become increasingly scarce. We had planned that at this point of transition we would cut a trail to the upper slopes and summit of the northern ridge, and if possible, follow the ridgetop around the drainage of the central valley by proceeding westwards, then south and then finally east along the southern ridgetop to fully survey for Nepenthes flora before making our descent.

A fter purchasing supplies and finding six native guides and porters with home-made, wooden and rattan backpacks, we began our trek, first following the rivers and streams as far as we could, and then the faint trails that passed, as we had suspected, hunting traps and great Agathis philippinensis resin trees (known locally as almaciga). The animal traps seemed mostly set up for catching birds, although we did pass hunting parties with dogs, long spears, and guns that were searching for wild boar. I had seen similar hunting parties on earlier expeditions to M ount Victoria and Sultan's Peak. 
The resin trees all bore alarming cuts and gashes gouged into their sides. These machete-carved parallel grooves run deep into the bark and are made periodically every few months. Over time, resin drains from the trees and accumulates below the wounds, slowly solidifying from a sticky oozing, transparent fluid, into a white, translucent, brittle mass that feels waxy to the touch. Once harvested, the resin is sold in local markets and used for making lacquer and wood varnish internationally, and for starting fires locally. The solid resin is an essential tool which all of the local hunters carry, and ignites even when wet, and burns with an intense, powerful flame. The resin collectors mainly live in shacks in the unwelcoming frontier between of the untamed wilderness and the rice padis, and commonly travel for many days or weeks, often passing kilometers to reach specific trees which they have previously prepared. The collectors are bound by a form of honorable code, and each one harvests resin only from the trees which he has personally carved - it would be too easy to steal resin from friends, neighbors, or enemies, though without unique markings, the collectors memorize where their trees are, and which ones they have prepared and when.

The resin collector's livelihood also depends upon an understanding that the trees should only bear cuts on three sides, not fully around their circumference which kills the trees completely. Unfortunately, in recent years, as more and more collectors seek resin, the Agathis trees have become increasingly drained of resin, causing large numbers of the trees to die, causing the remaining trees to be harvested with increasing frequency and intensity, with the result that the trees are increasingly endangered and have been almost entirely wiped out from many parts of the Philippines. Happily, large populations still remain in the remoter forested areas of Palawan, although the life of the collectors is nevertheless physically extreme, and collectors reap little reward. On earlier trips, I learned that the market price for a kilogram of resin may be 20 Philippine pesos (US $\$ 0.50$, or GB $£ 0.30$ ), and most resin collectors may collect only a few kilograms of resin each day.

On N ovember $18^{\text {th }}$, we reached the upper slopes of the northern ridge side of our goal, and the first open, lower montane forest that we had encountered. A round midday, we stepped into a small clearing and abruptly found an abandoned shelter made of cut hardwood sticks bound together with rattan cord, and roofed with weaved palm leaves. The construction rested against a great rock, and had been made by the sel dom seen Ta-ot B atu tribe who usually make their homes in the great caves of Palawan - indeed even their name translates to "people of the stone", but the Ta-ot B atu are very fearful of outsiders and shun modernity, still living a largely traditional hunting lifestyle. This was no doubt a hunting shelter, and it had been recently used - the palm-leaf roof of was still green, but I found green rattan cane inside and mounds of rice husks nearby. A fter a brief rest, we continued onwards, and left behind all sign of human presence.

As evening fell, we established camp high up on the exposed flanks of the ridgeside, close to the ridge summit itself. Our guides macheted a clearing among bamboo scrub and mossy trees and Greg, M ark, and I erected our tents, while the Filipino contingent of the expedition set up large tarpaulins and hammocks which they prefer. From this campsite, I could gain my first impressions of the vegetation of the ridgetop we were ascending. As far as I could discern, the ridgetop ahead appeared quite different from the other peaks that I had climbed in the Victoria $M$ assif in previous years - it was laden with thick montane forest and I began to wonder whether our ridge would be too low-lying or too vegetated to harbor highland N epenthes plants. As our party sat around a small wood fire in the fading light of dusk under a wet and dripping tarpaulin, Greg, M ark, and I discussed this possibility and hoped our efforts had not been in vain. But at that moment, just as we were in despair, I observed a familiar leaf with a tendril growing in heavy shade, in vegetation at the side of our campsite - a Nepenthes plant! It was a sickly specimen, surviving at the lowermost part of its altitudinal range. The plant was etiolated and devoid of traps 
and flowers, and so it was impossible to establish if it represented a known species or otherwise - this discovery would have to wait.

A fter a night of intense rainfall and heavy dew, the following morning we all awoke early to continue our ascent to the summit of the ridge. Progress became excruciatingly difficult as the el evation leveled off and the vegetation became ever denser and eventually impenetrable. We could proceed only by following our guides and porters who macheted a narrow path in front. We encountered a few Nepenthes plants on the ridgetop, and found several plants in pitcher - their traps were reminiscent of N. deaniana, N. gantungensis, and N. mira, but they bore a peristome that was flatter and broader than those three species, and we observed several plants with dark red, purple, or even pure black pitchers - coloration not known in any of the Palawan Nepenthes. A Ithough the traps were different in shape from N. deaniana, N. gantungensis, and N. mira, we determined to continue onwards with the goal of finding a higher point of altitude where a larger and healthier population of the Nepenthes plants to study. A fter a full day of cutting a trail, our GPS devices revealed that we had proceeded only a few hundred meters along the ridge top and so I climbed a tree to sight our path. As the clouds cleared in the distance, I caught view of a large, sharp-sided pyramidal peak looming above our ridge beyond a steep valley several hundred meters away. Separating us from the peak was an even, unbroken sea of dense vegetation al ong the ridgetop. We returned to the camp that we had established the previous evening, the macheted remains of the vegetation cutting into our legs as we scrambled down the narrow trail.

On arriving back at camp, we caught sight of the southerly arm of the complex through a clearing in the trees. We could see that our original goal of proceeding around the ridgetop to descend by way of the southern arm was impossible - it would have taken many weeks to machete around the full perimeter of the $\mathrm{U}$ formed by the ridgesides. To our frustration, we could see that the southerly ridge looked much more suitable for highland Nepenthes - it comprised of low growing, grassy scrub which is the known habitat of for giant N. attenboroughii and N. palawanensis type species which we had hoped to find. N either N. attenboroughii nor N. palawanensis occur in montane forest such as that which we were laboriously cutting our trail through on the northern ridgeside. We had only five days of provisions remaining, and so jointly decided to set our goal on reaching the summit of the pyramidal peak that I had seen through the mist.

The next morning, we awoke again early and roused the guides to continue macheting the trailhead. The laborious work grew more and more difficult, but after five hours or so we had reached the valley separating the ridgeside and the pyramidal peak, and began descending. A long the valley sides, Greg, M ark, and I found the Nepenthes plants growing rooted to cliffsides, with their great pitchers hanging down the cliffs in midair. We continued onwards, and suddenly and abruptly, the trail cut through into an open clearing of a vast swamp. Our guides and porters were as amazed as we were, for they had never seen or heard of such a place occurring on any mountain nearby, and immediately explained that this clearly showed no person had reached this spot previously since otherwise this wetland would have been cultivated as it made a perfect natural rice padi. In the swamp, we found large wallows, presumably made by wild pigs, and amongst the grasses, we discovered a sparse population of "D rosera sp. A" - a newly discovered sundew that occurs across several islands in South East A sia. It is a sundew which I had encountered on M ount Victoria and M ount M antalingahan on earlier expeditions that is closely related to D. spathulata, and occurs consistently on ultramafic substrate. The plant was previously known from seepage habitat on ultramafic rocks, but not in open, wet marsh such as we had found.

From the swampland, we had a clear view of the pyramidal peak that lay ahead of us. Our lead guide suggested that the mountain was Schom-carp Peak which was viewed and known from the 


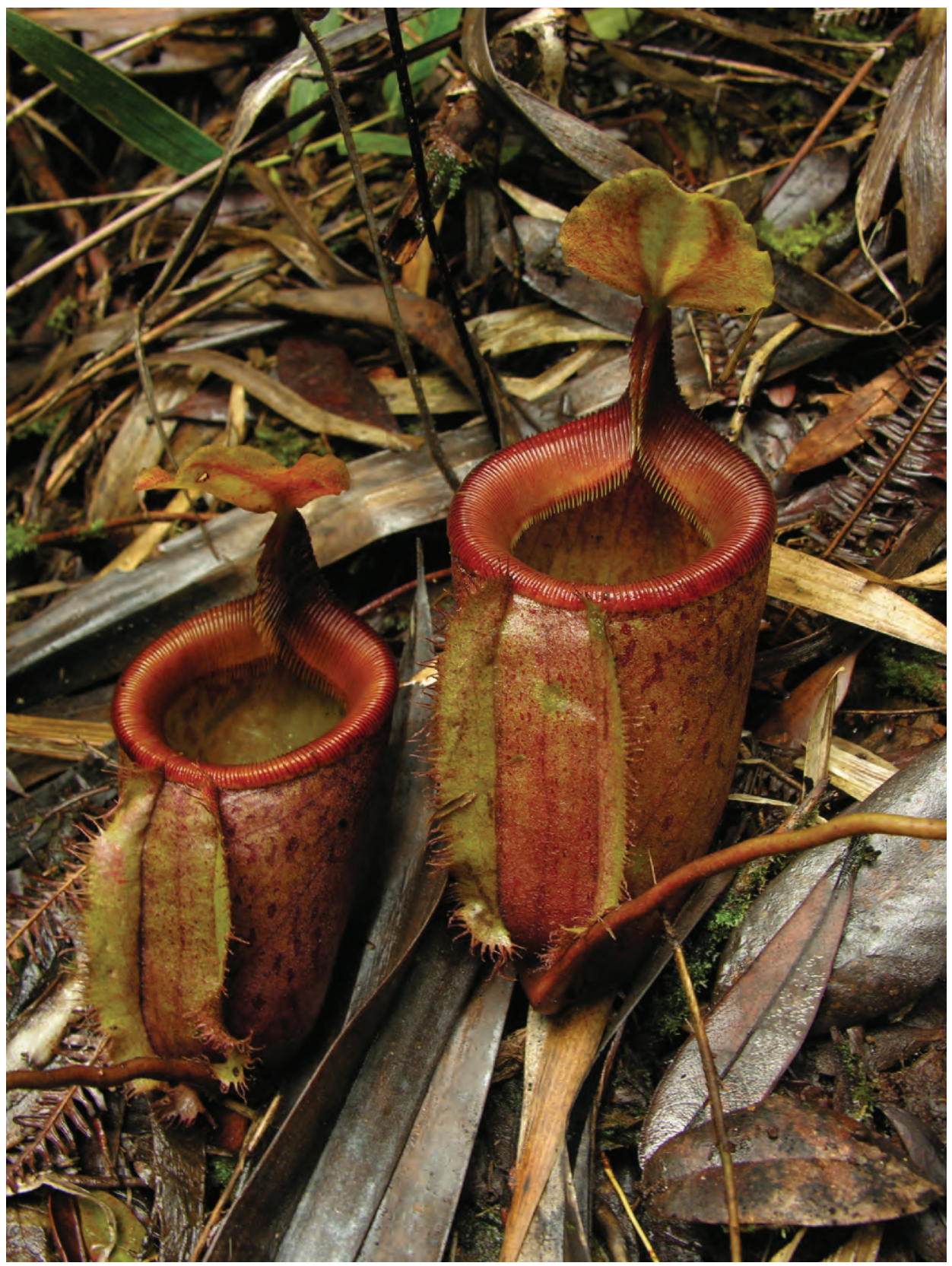

Figure 1: The lower pitchers of a Nepenthes leonardoi plant growing on the summit of Schom-carp Peak.

lowlands, but had never been ascended. A fter a short break, our party of guides continued macheting the trail ahead for the final assault, and three hours later, we finally reached the summit. A long the trail, the Nepenthes plants had become increasingly more common, and we found the species to be 


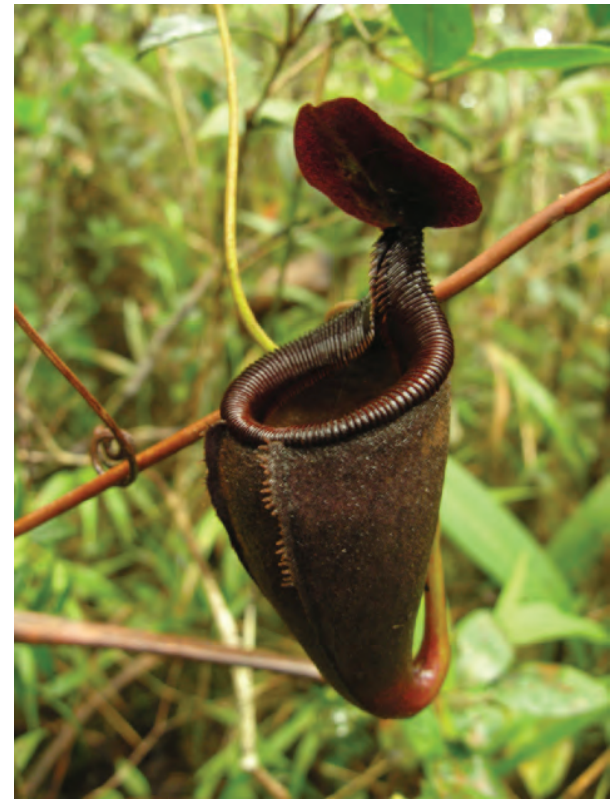

Figure 2: The striking dark upper pitchers of a color variant of a Nepenthes leonardoi plant. Note this pitcher is not dead - see photo on Back Cover in which a flash was used.

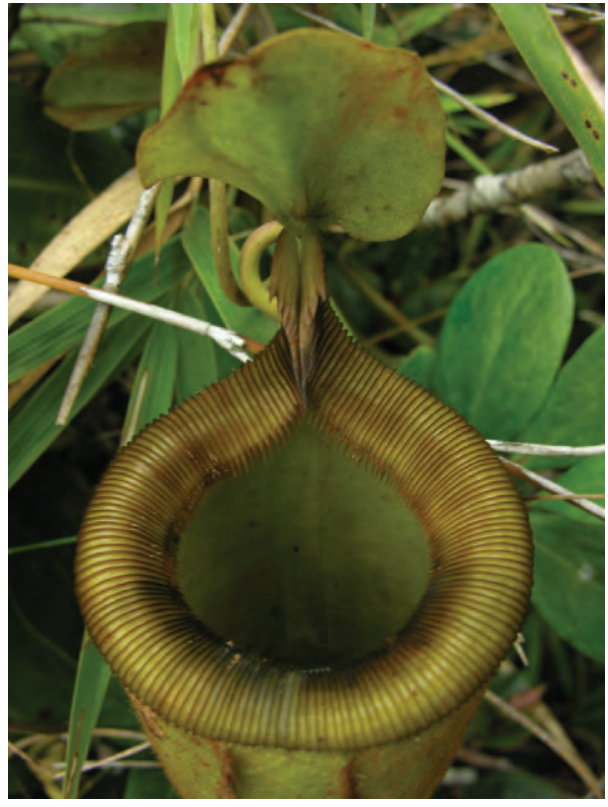

Figure 3: The broad peristome of an upper pitcher of a Nepenthes leonardoi plant. Note the prominent peristome ribs.

most populous in patches of lower bushy scrub on the summit. We found the most vigorous plants growing in direct sunlight amongst the shortest vegetation. In such habitat, the plants produced stout climbing rosettes bearing oblong leaves that bore similarity to those of N. deaniana, N. gantungensis, and N. mira. However, unlike those species, we observed few plants growing inside the montane forest vegetation bearing vines longer than two meters long. A nd although very closely related to those species, a systematic comparison of the leaves, pitchers, stem, and inflorescences revealed stable differences from all three species (M cPherson et al. 2011).

The Nepenthes produced stout lower pitchers up to $24 \mathrm{~cm}$ long, lined with a broad peristome bearing prominent peristome ribs that terminate into long, hard, sharp inward protruding spikes. Prominent wings ran down the front of the lower pitchers, and often the lid was elevated far above the pitcher opening on an elongated column of the peristome, lined with forward, enlarged protruding peristome spikes. The lid lacked an appendage, and the spur was narrow and up to $6 \mathrm{~mm}$ long. The latter characteristic confirmed our suspicions that the plant was more closely related to $\mathrm{N}$. deaniana, N. gantungensis, and N. mira than N. attenboroughii and N. palawanensis since the latter plants have very distinctive, exceptionally broad spurs.

The upper pitchers were very variable in color, but consistent in shape and overall characteristics (see Figure 1). At one extreme, we found a minority of plants with small, infundibular, purplish black upper traps (see Figure 2 and Back Cover), while the majority of specimens produced upper pitchers that were pure yellowish green, or green with an orangish-red peristome. The upper pitchers bore a more bulbous and prominent peristome than N. deaniana, N. gantungensis, and N. mira, and similar peristone ribs and inward protruding spikes comparable to the lower traps (see Figure 3). Often, a prominent ridge (although not a fully-formed appendage) was discernable on the lower 
surface of the lid, above the point of attachment with the peristome. The largest upper pitchers which I observed were $26 \mathrm{~cm}$ long, and unlike N. deaniana, N. gantungensis, and N. mira, upper pitchers were produced abundantly and in greater numbers on most plants than the lower traps. The inflorescences bore similarity to the N. deaniana, N. gantungensis, and N. mira group, but bore an exceptionally strong and distinctive odor (M cPherson et al. 2011).

On the morning of our sixth day, we began our descent, passing rapidly back along the trail we had cut, and past the Ta-ot B atu shelter. B efore nightfall, we had reached the lowlands, and managed to find a tricycle driver willing to take us to the nearest town for a much-needed night of relaxation, happy in the accomplishments of our expedition. When we reached the lowlands, we were sad to hear that day we had begun our climb, one of the great Filipino botanists and a personal friend, Leonardo $\mathrm{Co}$, had been shot dead along with two other botanist colleagues in L uzon, in fighting between communist rebels and the government troops. L eonardo had worked intensively for more than three decades, documenting traditional uses of native plants of the Philippines. It seems a sad irony that this black-pitchered plant was found as he had died. We decided together that we would name the plant Nepenthes leonardoi, to honor his lifetime's work to studying the Filipino plant life, including Nepenthes. Troublingly, I had traveled close to the forests where L eonardo had been shot during earlier expeditions.

The discovery of this plant reinforced thinking that the currently known Nepenthes species of Palawan fall into three natural groups. N. deaniana, N. gantungensis, N. mantalingajanensis, N. mira, and $\mathrm{N}$. leonardoi all bear similar morphology and ecology, but are distinguished from one another by minor but consistent structural foliar or floral differences. Of this group, N. mantalingajanensis is the most distinct in that it produces much small and uniquely shaped leaves that are an adaptation to its exposed habitat on $\mathrm{M} \mathrm{t}$. M antalingahan, the tallest peak on Palawan. Nepenthes attenboroughii and $\mathrm{N}$. palawanensis also form a very clear pair of closely related species, and are noteworthy for bearing some of the largest and most voluminous traps of all pitcher plants. A lthough very closely related, many clear morphological characteristics separate these two plants apart, not least that N. attenboroughii rapidly produces upper pitchers, whereas N. palawanensis produces only large, hairy, great lower traps even when fully mature and flowering. The third group comprises the only lowland species of Palawan, the endemic N. philippinensis which is more closely related to N. alata than any other palaweño Nepenthes (M cPherson 2009).

A great number of peaks on Palawan remain unexplored, not least the limestone outcrops scattered across the island which hold particular promise for possible endemic Nepenthes species. It certainly seems that we still have much to learn of the incredible and much underestimated diversity of the Nepenthes of the Philippines.

Photos and videos of this expedition and of Nepenthes leonardoi can be viewed at www. redfernnaturalhistory.com.

\section{Bibliography}

M cPherson, S. 2009. Pitcher Plants of the Old World Vols $1 \&$ 2. Redfern Natural History Productions L td., Poole, Dorset, England.

M cPherson, S., G. Bourke, A. Fleischmann, A. Robinson, and M. Jaunzems. 2011. A new pitcher plant from Palawan: Nepenthes leonardoi. Carniflora A ustralia, (The J ournal of the A ustralasian Carnivorous Plant Society) 8(1): 4-9. 


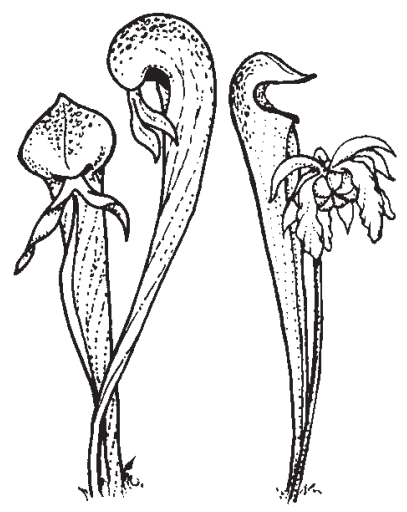

\section{CARNIVOROUS \\ PLANT \\ NEWSLETTER}

Journal of the International

Carnivorous Plant Society

www.carnivorousplants.org

\section{Volume 40, Number 1 March 2011}

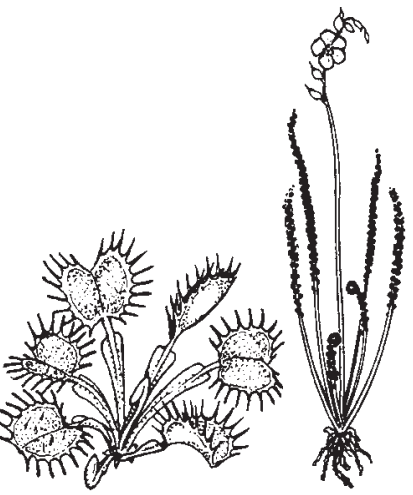

\section{Front Cover: Drosera tracyi growing with Pinguicula planifolia in temporarily flooded conditions; Apalachicola National Forest (Liberty County, Florida). Photo by Barry Rice. Article on page 4.}

Back Cover: The striking dark coloration of a dark color variant of the recently discovered Nepenthes leonardoi. Note the purple-colored exterior surface of the pitcher is lined with short, brown hairs. Photo by Stewart McPherson. Article on page 28.

Carnivorous Plant N ewsletter is dedicated to spreading knowledge and news related to carnivorous plants. Reader contributions are essential for this mission to be successful. Do not hesitate to contact the editors with information about your plants, conservation projects, field trips, or noteworthy events. A dvertisers should contact the editors. Views expressed in this publication are those of the authors, not the editorial staff.

All correspondence regarding dues, address changes and missing issues should be sent to the Membership Coordinator at the ICPS. Do not send such correspondence to the editors. Checks for subscriptions should be made to the ICPS in US funds. Dues for 2011 are \$35 for the first year of membership; renewals are $\$ 30$ per year.
ICPS, Inc.
PM B 322
1564-A Fitzgerald Drive
Pinole, CA 94564-2229, USA
icps@carnivorousplants.org

President Michael Baldwin, michael@ carnivorousplants.org

Vice President M Marcel van den Broek, marcel@ carnivorousplants.org

Secretary_ Cindy Slezak, cindy@ carnivorousplants.org

Treasurer

Richard M yers, richard@ carnivorousplants.org

B oard M ember Bob Ziemer, bob@carnivorousplants.org

B oard M ember Jan Schlauer, jan@ carnivorousplants.org

B oard M ember B B Bian Barnes, Conservation Director, brian@ carnivorousplants.org

Seed B ank M anager John B rittnacher, john@ carnivorousplants.org (see seed bank ad in this issue)

Editors:

M anaging Editor Bob Ziemer, bob@carnivorousplants.org

Science Editor Jan Schlauer, jan@ carnivorousplants.org

Science Editor Fernando Rivadavia, fernando@ carnivorousplants.org

Editor

Barry Rice, barry@ carnivorousplants.org

Date of effective publication of the December 2010 issue of Carnivorous Plant N ewsletter: 30 N ovember 2010.

The ICPS is the International Cultivar Registration A uthority (ICRA) for the names of cultivated carnivorous plants according to the International Code of Nomenclature for Cultivated Plants. Send relevant correspondence to the ICPS, Inc.

Carnivorous Plant Newsletter is published quarterly in M arch, June, September, and December by the ICPS, Inc. Periodicals postage pending at Richmond, $\mathrm{CA}$ and additional mailing offices. Postmaster: Send address changes to ICPS, Inc., PM B 322, 1564-A Fitzgerald Drive, Pinole, CA 94564-2229, USA. Printed by A llen Press, Inc., 810 E. 10 th Street, L awrence, K S 66044. L ogo and masthead art: Paul M ilauskas.

(c) 2011 Carnivorous Plant N ewsletter. All rights reserved. ISSN \#0190-9215 